\title{
Radioimmunoassay of human growth hormone: technique and application to plasma, cerebrospinal fluid, and pituitary extracts ${ }^{1}$
}

\author{
FRANCES J. THOMAS, H. M. LLOYD ${ }^{2}$, AND M. J. THOMAS \\ From the Department of Medicine (University of Queensland) and the Biochemistry Department, Royal \\ Brisbane Hospital, Brisbane, Australia
}

SYNOPSIS A radioimmunoassay for human growth hormone using activated charcoal is described and its precision, accuracy, and sensitivity are defined. Results are presented for growth hormone measurements in plasma obtained during hypoglycaemia induced with insulin in patients of short stature and during glucose tolerance tests in patients with acromegaly. The method was used to measure growth hormone concentrations in cerebrospinal fluid and in extracts of pituitary tumours. No growth hormone was detected in the cerebrospinal fluid of patients without acromegaly. In patients with acromegaly, the concentration of growth hormone in cerebrospinal fluid was measurable and was considerably elevated in one patient with extrasellar extension of a pituitary tumour. Extracts of chromophobe pituitary tumours contained very small concentrations of growth hormone. In extracts of pituitary tumours removed from acromegalic patients, concentrations fell either below or within the normal range.

A number of techniques are now available for the radioimmunoassay of human growth hormone $(\mathrm{GH})$. In this paper, we describe a method based on the dextran-coated charcoal procedure of Lau, Gottlieb, and Herbert (1966) and similar to that reported recently by Jacobs (1969). Our experience with this assay in the investigation of short stature and acromegaly is summarized and brief reference is made to measurements of GH concentration of cerebrospinal fluid and in extracts of pituitary tumour tissue.

\section{Materials and Methods}

BU F FER

Barbitone buffer, $0.07 \mathrm{M}, p \mathrm{H} 8.6$ containing $0.01 \%$ merthiolate, was used for preparing the charcoaldextran suspension and Sephadex columns.

\section{ALBUMIN BUFFER}

Bovine serum albumin (BSA) fraction V (Commonwealth Serum Laboratories, Melbourne), $0.5 \%$ in the barbitone buffer was used for diluting $\mathrm{GH}$

'Supported by a grant from the Queensland Cancer Fund.

'Address for reprints: Dr H. M. Lloyd, Department of Medicine, Clinical Sciences Building, Royal Brisbane Hospital, Brisbane, 4029, Australia.

Received for publication 31 May 1972. standards, antibody, and labelled hormone and for equalizing incubation volumes.

CHARCOAL-DEXTRAN SUSPENSION

A $2 \%$ solution of Dextran 250 (Pharmacia, Sweden) in barbitone buffer was added to an equal volume of a $20 \%$ suspension of charcoal (Norit A Neutral Pharmaceutical Grade Decolorising Carbon, Amend Drug Company, New York), also in barbitone buffer. The mixture was kept at $4^{\circ} \mathrm{C}$ and agitated constantly on a magnetic stirrer during dispensing.

HUMAN GROWTH HORMONE

A Wilhelmi preparation, HS $1103 \mathrm{C}$ supplied through 윽 the National Pituitary Agency of the United States, $D$ was used for iodination and standards. Material for iodination was stored at $-20^{\circ} \mathrm{C}$ in $50 \mu$ l aliquots $N$ containing $20 \mu \mathrm{g} \mathrm{GH}$ in $0.05 \mathrm{M}$ phosphate buffer $p H$ 7.5. Material for standards was dissolved in albumin buffer and $50 \mu \mathrm{l}$ aliquots containing $10 \mu \mathrm{g}$ of $\mathrm{GH}$ were stored at $-20^{\circ} \mathrm{C}$. Final dilutions were made immediately before an assay.

ANTIBODY

Antisera to human growth hormone were produced in guinea pigs and rabbits by dissolving approxi- 
mately $1 \mathrm{mg}$ of GH (Commonwealth Serum Laboratories Batch 003-3 or 007-1) in 0.5 ml saline, emulsifying with $0.5 \mathrm{ml}$ Freund's adjuvant and injecting subcutaneously at multiple sites. The animals were given injections once a fortnight for three injections followed by monthly booster doses. They were bled 10 days after the third and each booster injection. Near maximum antibody titre was usually obtained after the first booster dose. The most satisfactory antiserum, one from a guinea pig, was diluted to 1 in 10 with albumin buffer and stored in aliquots at $-20^{\circ} \mathrm{C}$. For use in the assay it was diluted to 1 in 45000 and kept at $4^{\circ} \mathrm{C}$.

HUMAN GROWTH HORMONE FREE PLASMA Plasma obtained from patients who had undergone hypophysectomy was added to GH standard tubes and used for diluting plasma samples with high GH levels.

${ }^{125}$ I - LA BELLED HUMAN GROWTH HORMONE

Freshly prepared columns of Sephadex G 50 $(1 \mathrm{~cm} \times 15 \mathrm{~cm})$ and $\mathrm{G} 100(1 \mathrm{~cm} \times 20 \mathrm{~cm})$ were packed in barbitone buffer, coated with $2 \%$ BSA in barbitone buffer and washed with barbitone buffer.

The iodination procedure was basically that of Greenwood, Hunter, and Glover (1963). Solutions of chloramine $\mathrm{T}(2 \mathrm{mg} / \mathrm{ml})$, sodium metabisulphite $(2.4 \mathrm{mg} / \mathrm{ml})$, and potassium iodide $(10 \mathrm{mg} / \mathrm{ml})$ were made up in $0.05 \mathrm{M}$ phosphate buffer $p \mathrm{H} \mathrm{7.5}$. To the reaction vial containing $10-20 \mu l(2 \mathrm{mCi})$ sodium iodide-125 solution (IMS 3, Radiochemical Centre)

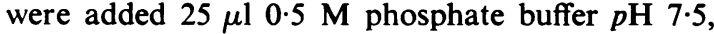

$25 \mu \mathrm{l} \mathrm{GH}$ solution $(10 \mu \mathrm{g})$, and $25 \mu$ l chloramine $\mathrm{T}$ solution.

The iodination was allowed to proceed for approximately 15 seconds and was stopped by the addition of $100 \mu \mathrm{l}$ sodium metabisulphite solution and $200 \mu \mathrm{l}$ potassium iodide solution.

The iodination mixture was transferred to a G 50 column and the vial was washed with potassium iodide solution $(400 \mu \mathrm{l})$ which was also transferred to the column. The column was eluted with barbitone buffer, $0.5 \mathrm{ml}$ fractions being collected into polystyrene tubes containing $5 \%$ BSA in barbitone buffer $(0.5 \mathrm{ml})$. Two peaks of radioactivity were obtained, protein- ${ }^{125} \mathrm{I}$ being followed by free iodide. The peak fraction and the first fractions on the trailing side of the protein-125I peak were diluted with $5 \%$ BSA in barbitone buffer, divided into $1 \mathrm{ml}$ aliquots, frozen, and stored for up to a month.

Calculation of specific activity, based on the assumption that radioactivity in the first peak divided by the total radioactivity eluted from the column represented the fraction of the ${ }^{125} \mathrm{I}$ incorporated into $\mathrm{GH}$, yielded values of 114 to $168 \mu \mathrm{Ci} / \mu \mathrm{g}$.

On the day of assay a $1 \mathrm{ml}$ aliquot was thawed and placed on a G 100 column. Three peaks of radioactivity were eluted with barbitone buffer, $0.5 \mathrm{ml}$ fractions being collected as before. The peak fraction from the second peak (immunoreactive $\mathrm{GH}$ ) was diluted to about $7500 \mathrm{cpm} / 50 \mu \mathrm{l}$ for use in the assay. Immediately after iodination this was the major peak, but during storage a continuous breakdown of labelled GH occurred and the first ('aggregate') and third ('iodide') peaks became increasingly prominent

Fig. 1 Elution pattern of radioactivity of ${ }^{125}$ I-labelled growth hormone after chromatography on Sephadex $G$ 100. On left, one day after iodination; on right, after storage for 22 days.

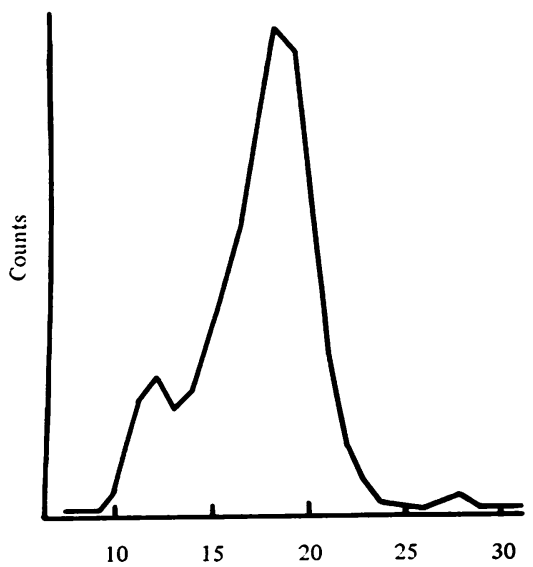

30

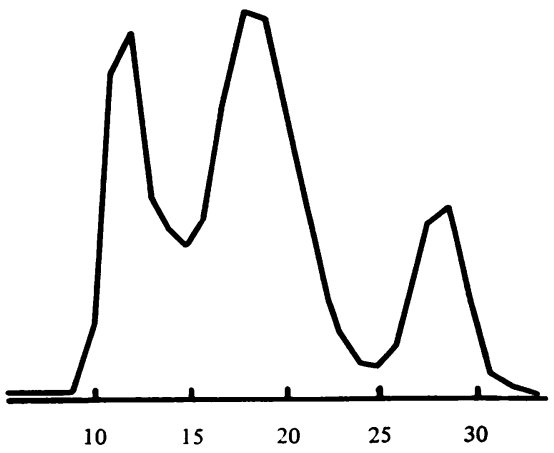

Fraction No. 
(Fig. 1). There was a concurrent lowering of the specific activity of the immunoreactive $\mathrm{GH}$ as indicated by a decrease in the $B / F$ ratio at the zero GH point and in the slope of the standard curve.

\section{Assay Procedure}

Incubations were carried out in 0.3 in. $\times 3.0$ in. disposable tubes. Fifty $\mu$ l growth hormone-free human plasma was added to 20 tubes for the standard curve. Fifty $\mu$ l of unknown plasma samples was added in quadruplicate to the remaining tubes to provide duplicate test and non-specific binding control tubes. Fifty $\mu$ l of solutions of the reference preparation of GH was added in duplicate at the following concentrations: $0 \cdot 1,0 \cdot 2,0 \cdot 3,0 \cdot 4,0 \cdot 5,0 \cdot 7$, 1.0 , and $1.5 \mathrm{ng} / 50 \mu \mathrm{l}$ to tubes containing hypophysectomized human plasma. Fifty $\mu$ l of suitably diluted antiserum was added to all tubes of the standard curve (except two control tubes which received only hypophysectomized human plasma, tracer, and buffer) and to the two test samples for each unknown plasma. Five hundred $\mu$ l of albumin buffer was added to the control tubes, $450 \mu l$ to the test samples, and $400 \mu \mathrm{l}$ to the standard tubes that received added $\mathrm{GH}$. Thus the final volume in all tubes was $550 \mu \mathrm{l}$. The contents of the tubes were mixed and the reaction was allowed to proceed at $4^{\circ} \mathrm{C}$ for 48 hours when $50 \mu$ l of tracer solution was added. The solutions were mixed again and incubated for a further 24 hours. Charcoal suspension, $0 \cdot 4$ $\mathrm{ml}$, was added to each tube and after centrifugation at $1600 \times g$ for 15 minutes, the supernatant was aspirated off. The charcoal pellets in the tubes were counted in a well-type counter. In the zero antibody control tubes the counts on the charcoal (N) served as the corrected totals for the individual plasmas while the percentage of added radioactivity not adsorbed by the charcoal represented the nonspecific binding. The counts on the charcoal in the tubes containing antibody represented the free fraction (F). The bound fraction (B) was obtained by difference. The $B / F$ ratio was then $\frac{N-F}{F}$ or $\mathrm{N}$ $\bar{F}-1$ and the degree of non-specific binding was $100-\frac{N}{T}$ where $T$ was the total number of counts added to each tube.

The assay had a working range of 0 to $1.5 \mathrm{ng} \mathrm{GH}$ or 0 to $30 \mathrm{ng} / \mathrm{ml}$ plasma. Samples containing $>30$ $\mathrm{ng} / \mathrm{ml}$ plasma were diluted with growth hormonefree human plasma and re-assayed.

With the charcoal method the protein concen-

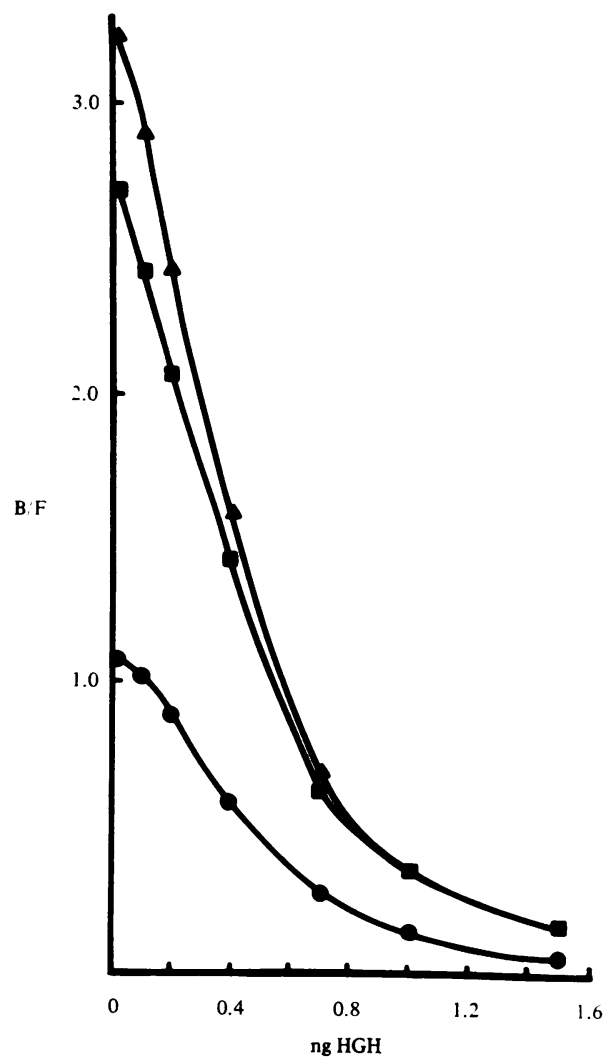

Fig. 2 Radioimmunoassay of growth hormone: standard curves obtained in buffer alone (O), with $20 \mu$ plasma added $(\square)$ and $50 \mu$ plasma added $(\Delta)$.

tration of the incubation mixture in all tubes should be as nearly as possible identical as it affects not only the degree of non-specific binding but also the behaviour of the charcoal in separating bound and free hormone. When standards were assayed in buffer alone non-specific binding was minimal but the standard curve was much lower than those obtained when $20 \mu$ l or $50 \mu$ l of growth hormone-free human plasma was added (Fig. 2). This occurred despite application of the correction factors described above and by Jacobs (1969), Meek, Stoskopf, and Bolinger (1970) and by Virasero, Capinschi, Bruno, and Leclercq (1971). Raising the amount of plasma to $100 \mu \mathrm{l}$ further increased the non-specific binding and tended to raise the standard curve again. The use of horse serum (Commonwealth Serum Laboratories 'for tissue culture') proved unsatisfactory as standard curves in $50 \mu \mathrm{l}$ fell below those in $50 \mu \mathrm{l}$ of the human plasma even though the non-specific binding of the horse serum was higher.

With pituitary extracts, dilution factors were such 
that samples could be diluted in albumin buffer and read against standard curves set up in this buffer. However, hypophysectomized human plasma $(50 \mu \mathrm{l})$ was routinely added to both the standard tubes and the diluted samples in order to improve the slope of the standard curve. Samples of cerebrospinal fluid were assayed in the same way.

Over 40 assays, the mean non-specific binding of the control $\mathrm{GH}$ free plasma used in the standard tubes was $8.6 \pm 1.7 \%$ (SD). The non-specific binding of tracer by most plasma samples was similar to this. It was noticed, however, that in patients taking oral contraceptives the non-specific binding was considerably higher (Table I).

\begin{tabular}{|c|c|c|c|c|}
\hline \multirow[t]{2}{*}{ Subject } & \multirow[t]{2}{*}{ Oestrogen } & \multirow{2}{*}{$\begin{array}{l}\text { Amount } \\
(\text { mg/day })\end{array}$} & \multicolumn{2}{|c|}{ Non-specific Binding ( $\%)$} \\
\hline & & & $\begin{array}{l}\text { Subject's } \\
\text { Plasma }\end{array}$ & $\begin{array}{l}\text { HGH-free } \\
\text { Control } \\
\text { Plasma }\end{array}$ \\
\hline v.c. & $\begin{array}{l}\text { Ethinyl } \\
\text { oestradiol }\end{array}$ & 0.05 & $13 \cdot 8$ & 8.9 \\
\hline $\begin{array}{l}\text { G.N. } \\
\text { I.M. }\end{array}$ & $\begin{array}{l}\text { Mestranol } \\
\text { Mestranol }\end{array}$ & $\begin{array}{l}0.15 \\
0.15\end{array}$ & $\begin{array}{l}14 \cdot 7 \\
16 \cdot 1\end{array}$ & $\begin{array}{r}9.5 \\
11.8\end{array}$ \\
\hline
\end{tabular}

Table I Non-specific binding of tracer by plasma of patients taking oral contraceptives

\section{SPECIFICITY}

Specificity of the assay was demonstrated by parallelism between the dilution curve of an acromegalic

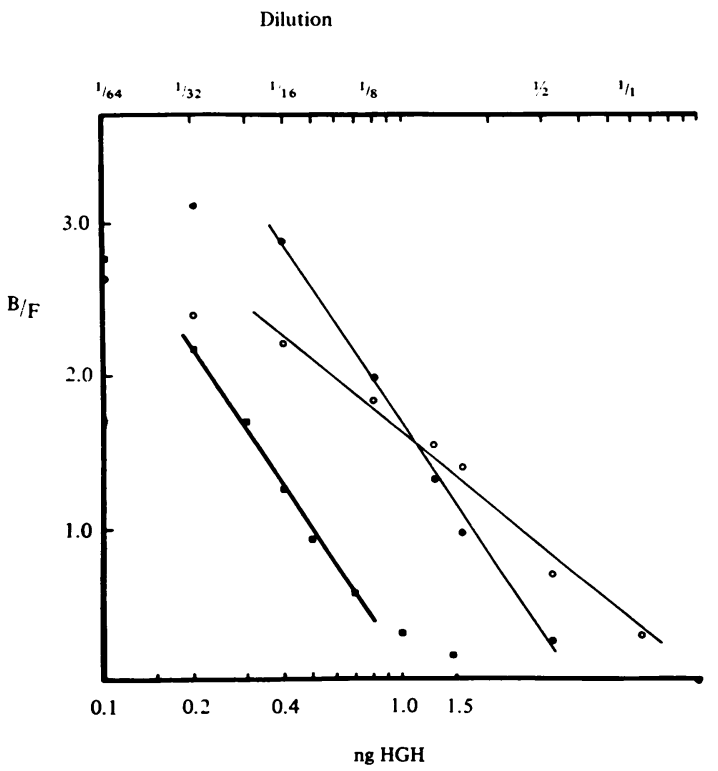

Fig. 3 Dilution curves obtained with growth hormone standard $(\square)$ plasma from an acromegalic patient $(\bigcirc)$ and plasma from an acromegalic patient during pregnancy (O). plasma and that of the GH standards plotted logarithmically (Fig. 3). The dilution curve of plasma from a pregnant acromegalic patient was not parallel with the other two. Cross reaction with placental lactogen could account for this as the dilution curve of a postpartum sample from this patient was parallel with that of growth hormone.

\section{PRECISION}

The results of replicate determinations on two plasma samples in separate assays are shown in Table II.

\begin{tabular}{llccc}
\hline Sample & $\begin{array}{l}\text { No. of } \\
\text { Assays }\end{array}$ & $\begin{array}{c}\text { Mean } \\
(\mathrm{ng} / \mathrm{ml})\end{array}$ & $S D$ & $\begin{array}{l}\text { Interassay Coefficient of } \\
\text { Variation (\%) }\end{array}$ \\
\hline I & 98 & $7 \cdot 78$ & 0.88 & $\begin{array}{r}11.4 \\
7.8\end{array}$ \\
II & 8 & 10.84 & 0.85 & 7.8 \\
\hline
\end{tabular}

Table II Results of replicate determinations on two plasma samples in separate assays

\section{ACCURACY}

Three different amounts of $\mathrm{GH}$ were added to duplicate $50 \mu \mathrm{l}$ aliquots of each of four plasma samples with GH levels of $7 \cdot 2,5 \cdot 0,3 \cdot 2$, and $2 \cdot 0$ $\mathrm{ng} / \mathrm{ml}$. Mean recoveries were $82 \%$ for $0.2 \mathrm{ng}, 89 \%$ for $0.4 \mathrm{ng}$, and $96 \%$ for $0.5 \mathrm{ng}$.

\section{SENSITIVITY}

The mean sensitivity, derived from the $95 \%$ confidence limits of the zero growth hormone points of 40 stanoard curves, was $0.43 \mathrm{ng} / \mathrm{ml}$.

\section{PATIENTS}

Growth hormone assays were carried out on patients who were resting after an overnight fast. A cannula was inserted intravenously in nearly all patients. Plasma GH was measured either during hypoglycaemia induced with soluble insulin Novo in an intravenous dose of 0.1 to $0.15 \mathrm{u} / \mathrm{kg}$ body weight, or after administration of $100 \mathrm{~g}$ glucose by mouth. In two patients with acromegaly, blood samples were taken at one to two hourly intervals to study GH levels throughout a period of 24 hours.

Blood glucose was measured in a Technicon AutoAnalyzer by the ferricyanide method of Hoffman (1937) and plasma cortisol by the method of Mattingly (1962).

\section{Pituitary Tissue}

Tissue obtained from patients who underwent hypophysectomy was stored at $-27^{\circ} \mathrm{C}$ under glycerol until extracted. Portions of the tissue were 
homogenized in Tris-EDTA-boric acid buffer at $p H$ 8.9 and GH concentrations were measured in the supernatants removed after centrifugation (Lloyd, Donald, Catt, and Burger, 1969).

\section{Cerebrospinal Fluid}

Cerebrospinal fluid was obtained for GH assay during air encephalography in five acromegalic patients.

\section{Results}

\section{SHORT STATURE}

Fifty-nine children were tested with insulin hypoglycaemia. Fasting serum GH levels of less than $2 \mathrm{ng} / \mathrm{ml}$ with no rise during a fall in blood glucose to less than half of the initial value were found in six of the children (five boys and one girl).

Twelve of these children, all boys with delayed puberty and between the ages of 14 and 18 years, showed a diminished GH response when compared with a group of six normal adult males, although a value greater than $6 \mathrm{ng} / \mathrm{ml}$ was found in each boy at some stage during the test. The plasma cortisol response did not differ from normal (Fig. 4).

GROWTH HORMONE DEFICIENCY WITH NORMAL PLASMA CORTISOL RESPONSE

Insulin hypoglycaemia induced in six patients resulted in elevation of plasma cortisol with no significant change in plasma GH (Table III).

\section{ACROMEGALY}

The diagnosis of acromegaly was based on the clinical findings together with lack of suppression in plasma GH during a $100 \mathrm{~g}$ oral glucose tolerance test. In normal subjects, plasma GH usually fell to less than $2 \mathrm{ng} / \mathrm{ml}$, followed by a rise at four to six hours. Acromegalic patients showed three kinds of response: (a) no consistent change in $\mathrm{GH}$ concentrations, which were greater than $4 \mathrm{ng} / \mathrm{ml}$ throughout the test (four patients). The patient J.S. had been treated with
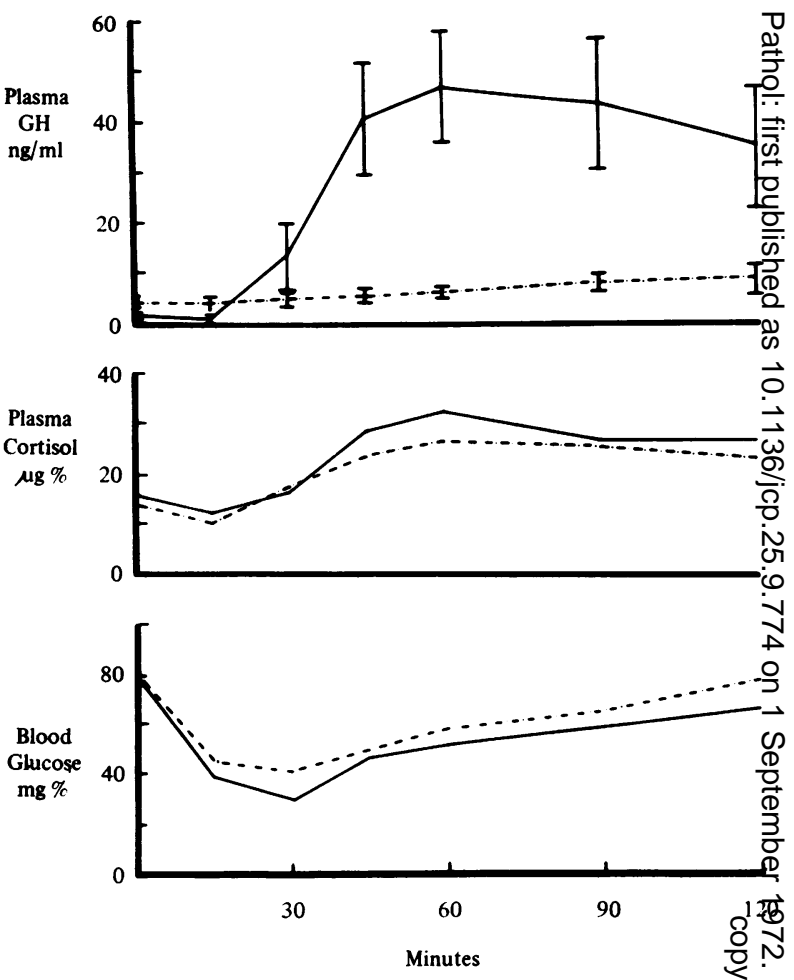

Fig. 4 Mean values (and standard error) for plasma $G F_{5}$ plasma cortisol, and blood glucose during insulin-induced: hypoglycaemia in 12 boys with delayed puberty (---) and in six normal adult males (-).

radiotherapy (Fig. 5); (b) high GH concentrations with a response in the normal direction, ie, a fall in plasma $\mathbf{G H}$ as blood glucose increased, followed by a rise to greater than fasting levels (six patients) (Fig. 6); (c) a paradoxical response, expressed as a rise instead of a fall in plasma GH accompanying elevation of the blood glucose (three patients) (Fig. 7).

A male patient (E.L.) in group $b$ studied at intervals of two hours throughout a 24-hour period

\begin{tabular}{|c|c|c|c|c|c|c|}
\hline \multirow[t]{2}{*}{ Patient } & \multirow[t]{2}{*}{ Age } & \multirow[t]{2}{*}{ Sex } & \multirow[t]{2}{*}{ Diagnosis } & \multicolumn{2}{|c|}{$\begin{array}{l}\text { Plasma Cortisol } \\
(\mu \mathrm{g} / 100 \mathrm{ml})\end{array}$} & \multirow{2}{*}{$\begin{array}{l}\text { Maximum } \\
\text { Plasma } H G H \\
(n g / m l)\end{array}$} \\
\hline & & & & Fasting & Maximum & \\
\hline $\begin{array}{l}\text { T.G. } \\
\text { L.M. }\end{array}$ & $\begin{array}{l}34 \\
31\end{array}$ & $\begin{array}{l}\mathbf{M} \\
\mathbf{F}\end{array}$ & $\begin{array}{l}\text { Chromophobe adenoma } 10 \text { months postoperatively } \\
\text { Short stature, primary amenorrhoea, intracranial A-V malformation, } \\
\text { subarachnoid haemorrhage }\end{array}$ & $\begin{array}{l}14 \cdot 4 \\
22 \cdot 0\end{array}$ & $\begin{array}{l}25 \cdot 2 \\
27 \cdot 0\end{array}$ & $\begin{array}{l}1 \cdot 2 \\
0 \cdot 4\end{array}$ \\
\hline $\begin{array}{l}\text { I.J. } \\
\text { L.I. } \\
\text { E.L. } \\
\text { H.L. }\end{array}$ & $\begin{array}{l}15 \\
18 \\
22 \\
16\end{array}$ & $\begin{array}{l}\mathbf{M} \\
\mathbf{F} \\
\mathbf{M} \\
\mathbf{M}\end{array}$ & $\begin{array}{l}\text { Craniopharyngioma three months postoperatively } \\
\text { Cushing's syndrome six months after cryohypophysectomy } \\
\text { Hypopituitarism } \\
\text { Hypopituitarism }\end{array}$ & $\begin{array}{r}5 \cdot 0 \\
20 \cdot 0 \\
3 \cdot 3 \\
4 \cdot 6\end{array}$ & $\begin{array}{r}8 \cdot 0 \\
25 \cdot 0 \\
7 \cdot 7 \\
10 \cdot 6\end{array}$ & $\begin{array}{l}0.4 \\
0.4 \\
0.8 \\
0.5\end{array}$ \\
\hline
\end{tabular}

Table III Details of GH and plasma cortisol responses to hypoglycaemia in six patients with pituitary disorders 

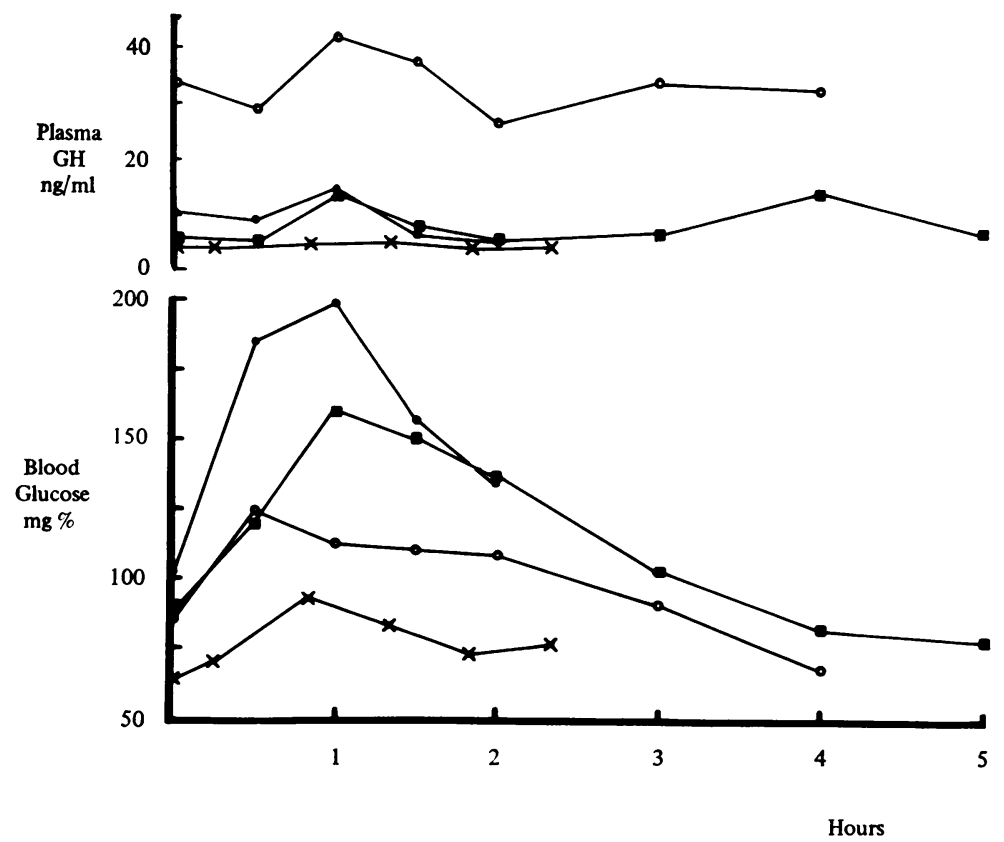

Fig. 5 Plasma $G H$ levels during glucose tolerance tests in four patients with acromegaly showing no consistent change (group a

- D.D., $\bigcirc J . A ., \square$ F.F., $\times$ J.S.).

Hours
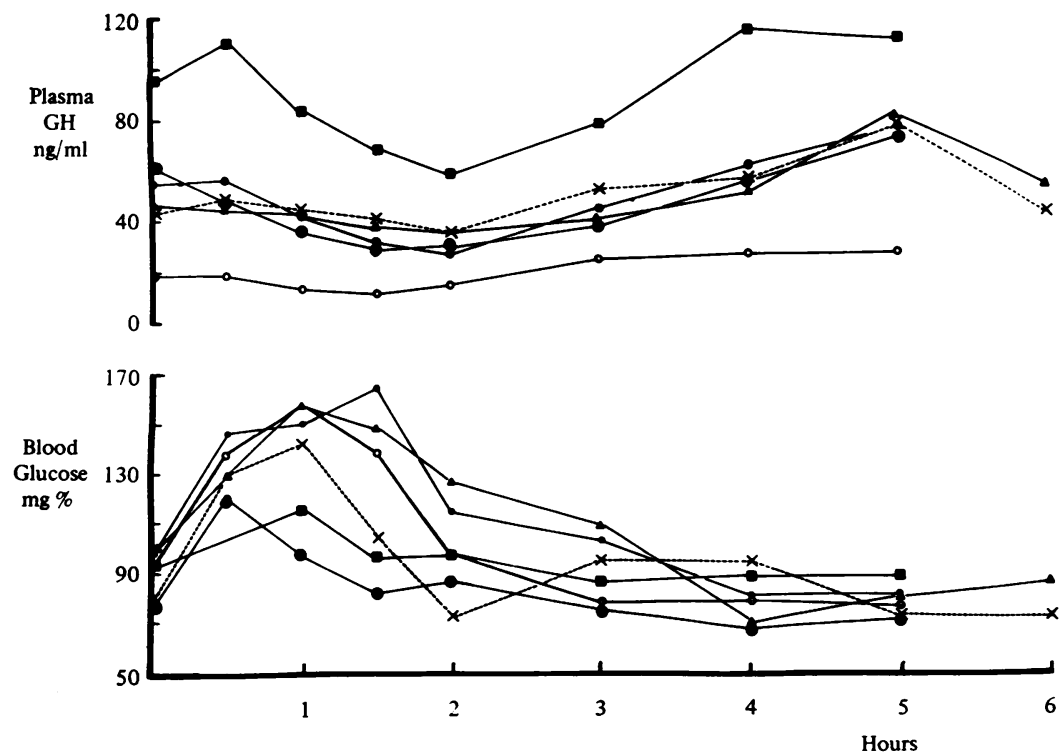

Fig. 6 Plasma $\mathrm{GH}$ levels during glucose tolerance tests in six patients with acromegaly showing $a$ fall in plasma $G H$ followed by a rise (group b J.J., $\triangle$ I.H., $\square$ M.S., $\bigcirc$ E.L., J.S., $\times$ E.S.). 


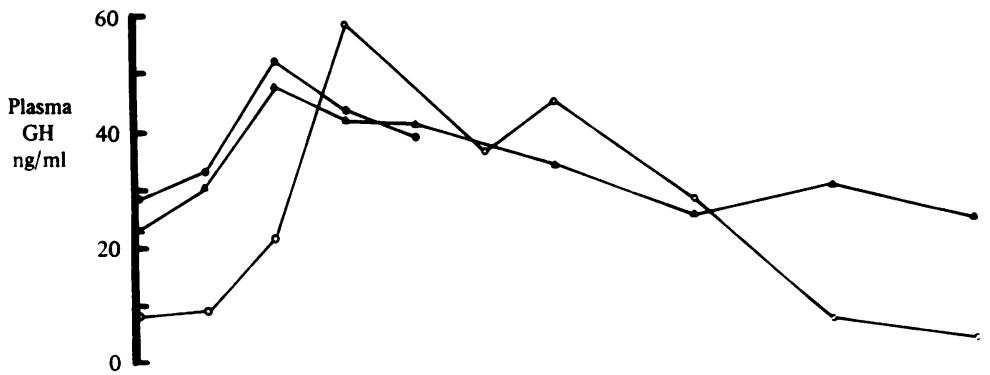

Fig. 7 Plasma GH levels during glucose tolerance tests in three pacients with acromegaly showing a 'paradoxical' response (group C $\triangle$ T.T., $\bigcirc$ K.L., ○ D.C.).

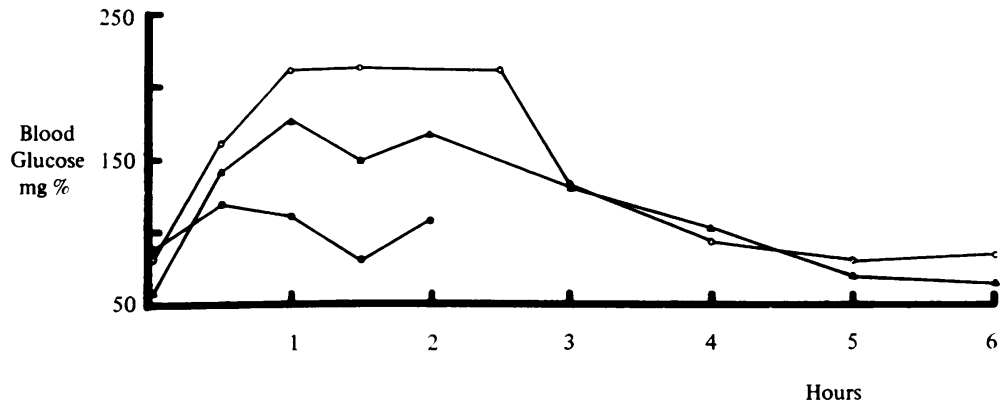

in hospital showed fluctuations in plasma $\mathrm{GH}$ between 10 and $25 \mathrm{ng} / \mathrm{ml}$. A female patient (K.L.) in group $c$ showed a range of plasma $\mathrm{GH}$ of 10 to 60 $\mathrm{ng} / \mathrm{ml}$ measured at intervals of one to two hours throughout a 24-hour period. In each of these patients, the range of serum GH values and the direction of change in relation to blood glucose levels were similar to the findings during prolonged glucose tolerance tests.

In a series of 18 untreated acromegalic patients, no significant correlation $(r=0.23)$ was found between mean plasma $\mathrm{GH}$ during a glucose tolerance test and area of the pituitary fossa measured in a lateral radiograph.

\section{CONCENTRATIONS OF GROWTH HORMONE IN PITUITAR Y TISSUE}

Three patients with acromegaly underwent transfrontal craniotomy and excision of the pituitary tumour. Two (J.A. and F.F.) were in group $a$ showing no consistent changes in plasma $\mathbf{G H}$ during a glucose tolerance test. Pituitary $\mathbf{G H}$ concentrations were $2.8 \mu \mathrm{g} / \mathrm{mg}$ (wet weight) and $12.8 \mu \mathrm{g} / \mathrm{mg}$. In the third patient (M.S.), plasma GH levels responded in a normal direction as the blood glucose rose and fell (group b). The GH concentration in her pituitary tumour was $28.5 \mu \mathrm{g} / \mathrm{mg}$. In eight normal anterior pituitary glands, the range of $\mathrm{GH}$ concentration was 8.4 to $49.4 \mu \mathrm{g} / \mathrm{mg}$ (mean 29.7 ). Very small concentrations of $\mathrm{GH}$ were found in extracts of chromo- phobe pituitary tumours removed from two patient with hypopituitarism $(0.0067 \mu \mathrm{g} / \mathrm{mg}$ and $0.084 \mu \mathrm{g} / \mathrm{mg})$

CONCENTRATIONS OF GROWTH HORMONE IN CEREBROS PINAL FLU ID

Cerebrospinal fluid protein concentrations in all samples were within the normal range. The results are summarized in Table IV. In one patient (C.N.)

\begin{tabular}{|c|c|c|c|c|}
\hline \multirow[t]{2}{*}{ Patient } & \multirow[t]{2}{*}{ Age } & \multirow[t]{2}{*}{ Sex } & \multicolumn{2}{|l|}{ Growth Hormone } \\
\hline & & & $\begin{array}{l}\text { Cerebrospinal Fluid } \\
(\mathrm{ng} / \mathrm{ml})\end{array}$ & $\begin{array}{l}\text { Plasma } \\
(\mathrm{ng} / \mathrm{ml})\end{array}$ \\
\hline M.A. & 41 & $\mathbf{M}$ & $1 \cdot 2$ & 60 \\
\hline E.L. & 23 & $\mathbf{M}$ & $0 \cdot 6$ & $\begin{array}{l}\text { 7-18 } \\
\text { during GTT }\end{array}$ \\
\hline B.M. & 47 & $\mathbf{M}$ & $\begin{array}{l}0.6 \\
0 \cdot 4\end{array}$ & $\begin{array}{l}\text { 6-14 } \\
\text { during GTT }\end{array}$ \\
\hline C.N. & 32 & $\mathbf{M}$ & $\begin{array}{r}12.6 \\
8.9 \\
11.6\end{array}$ & $7 \cdot 7$ \\
\hline J.S. & 46 & $\mathbf{F}$ & $\begin{array}{r}11.6 \\
1.0 \\
0.6\end{array}$ & 30 \\
\hline
\end{tabular}

Table IV Growth hormone concentrations in cerebrospinal fluid and plasma in acromegaly

the GH concentration in cerebrospinal fluid was considerably elevated and pituitary tumour tissue was found to be present outside the pituitary fossa at craniotomy. In the other acromegalic patients, there was no evidence of extrasellar extension on air encephalography and craniotomy was not performed. 
Growth hormone was undetectable $(<0.4 \mathrm{ng} / \mathrm{ml})$ in cerebrospinal fluid with normal protein concentrations taken from three non-acromegalic patients.

\section{Discussion}

The method described for the radioimmunoassay of GH has proved to be simple to perform and reliable as assessed by statistical analysis of the data obtained. The results in the various clinical groups require only brief discussion since they are generally in accordance with numerous published reports. In children of short stature, precise criteria, based on GH assay, for the diagnosis of GH deficiency cannot yet be defined but it is now clear that reliance on the insulin hypoglycaemia test alone is not acceptable (Raiti and Blizzard, 1970). Delayed puberty, when associated with short stature, may only be differentiated from GH deficiency by GH assay but in boys testing during treatment with androgen may be required in some cases to determine whether or not the pituitary gland is able to secrete GH (Eastman, Lazarus, Stuart, and Casey, 1971).

The group of patients with evidence of $\mathrm{GH}$ deficiency but relatively intact plasma cortisol response to hypoglycaemia (Table III) included two brothers (E.L. and H.L.) who were also deficient in TSH and gonadotrophin. In patient L.M., the arteriovenous malformation was believed to be congenital and the association of primary amenorrhoea, short stature, and intact adrenocortical and thyroid function presumably resulted from effects of the lesion upon hypothalamic and/or pituitary function. The patient was investigated shortly after a subarachnoid haemorrhage, an event which may itself affect pituitary responsiveness (Jenkins, Buckell, Carter, and Westlake, 1969).

Our findings in acromegaly illustrate the diagnostic value of the GH assay but, in occasional cases, a confident clinical diagnosis of acromegaly was not confirmed by plasma GH levels during a glucose tolerance test. Our results for $\mathrm{GH}$ concentrations in cerebrospinal fluid agree with those reported by Linfoot, Garcia, Wei, Fink, Sarin, Born, and Lawrence (1970) suggesting that this measurement may be useful in the diagnosis of extrasellar extension of a pituitary tumour in conjunction with air encephalography. A significant correlation between pituitary size and serum GH concentrations was reported by Wright, McLachlan, Doyle, and Fraser (1969) for their series of 84 cases of acromegaly. Our much smaller series of 18 cases did not show this correlation, possibly because it included five patients with pituitary fossa area within normal limits and only one patient with mean plasma GH greater than $100 \mathrm{ng} / \mathrm{ml}$. The very wide range of concentration of
GH in pituitary tumour tissue in acromegaly (Young, Bahn, and Randall, 1965; Lloyd et al, 1969) comprises part of the evidence put forward by Young et al (1965) that qualitatively different types of tumour may cause this disease. A given tumour may be heterogeneous in cell type and function but the existence of strongly eosinophilic tumours rich in GH and chromophobe tumours with very low GH concentrations, both causing acromegaly, is reasonably well established. It is of interest that lack of $\mathrm{GH}$ response to glucose was found in two of our patients whose tumours showed very low (J.A.) and low normal (F.F.) concentrations of growth hormone. While secretory autonomy is rarely complete in acromegaly as judged by responses to a battery of stimulatory tests (Cryer and Daughaday, 1969; Lawrence, Goldfine, and Kirsteins, 1970), it remains possible that failure to store GH may be characteristic of a group of pituitary tumours with relatively autonomous secretory activity.

We are grateful to physicians at the Royal Brisbane Hospital and other colleagues for referring patients for investigation. We thank Mrs Joan Jacobi and Mrs Carmel Ryan for expert technical assistance, Drs R. H. Mortimer, D. E. Lind, and J. E. Arnold for carrying out the tests on patients, and Miss Miriam Margulies for typing the manuscript. Human growth hormone was generously supplied by the National Pituitary Agency, USA.

\section{References}

Cryer, P. E., and Daughaday, W. H. (1969). Regulation of growth hormone secretion in acromegaly. J. clin. Endocr., 29, 386-393.

Eastman, C. J., Lazarus, L., Stuart, M. C., and Casey, J. H. (1971) The effect of puberty on growth hormone secretion in boys with short stature and delayed adolescence. Aust. N.Z. J. Med., 1, 154-159.

Greenwood, F. C., Hunter, W. M., and Glover, J. S. (1963). The preparation of ${ }^{131}$ I-labelled human growth hormone of high specific radioactivity. Biochem. J., 89, 114-123.

Hoffman, W. S. (1937). Rapid photoelectric method for determination of glucose in blood and urine. J. biol. Chem., 120, 51-55.

Jacobs, H. S. (1969). Use of activated charcoal in the radioimmunoassay of human growth hormone in plasma.J. clin. Path., 22, 710-717

Jenkins, J. S., Buckell, M., Carter, A. B., and Westlake, S. (1969) Hypothalamic-pituitary-adrenal function after sub-arachnoid haemorrhage. Brit. med. J., 4, 707-709.

Lau, K. S., Gottlieb, C. W., and Herbert, V. (1966). Preliminary report on coated charcoal immunoassay of human chorionic 'growth hormone-prolactin' and growth hormone. Proc. Soc. exp. biol. (N.Y.), 123, 126-131

Lawrence, A. M., Goldfine, I. D., and Kirsteins, L. (1970). Growth hormone dynamics in acromegaly. J. clin. Endocr., 31, 239-247.

Linfoot, J. A., Garcia, J. F., Wei, W., Fink, R., Sarin, R., Born, J. L., and Lawrence, J. H. (1970). Human growth hormone levels in cerebrospinal fluid. J. clin. Endocr., 31, 230-232.

Lloyd, H. M., Donald, K. J., Catt, K. J., and Burger, H. G. (1969). Growth hormone concentration in human pituitary tumours. $J$. Endocr., 45, 133-134. 
Mattingly, D. (1962). A simple fluorimetric method for the estimation of free 11-hydroxycorticoids in human plasma. J. clin. Path., 15, 374-379.

Meek, J. C., Stoskopf, M. M., and Bolinger, R. E. (1970). Optimization of radioimmunoassay of human growth hormone by the charcoal-dextran technique. Clin. Chem., 16, 845-848.

Raiti, S., and Blizzard, R. M. (1970). Human growth hormone: current knowledge regarding its role in normal and abnormal metabolic states. Advanc. Pediat., 17, 99-123.
Virasoro, E., Copinschi, G., Bruno, O. D., and Leclercq, R. (1971). Radioimmunoassay of human growth hormone using a charcoal dextran separation procedure. Clin. chim. Acta, 31, 294-297.

Wright, A. D., McLachlan, M. S. F., Doyle, F. H., and Fraser, T. R. (1969). Serum growth hormone lev:ls and size of pituitary tumour in untreated acromegaly. Brit. med. J., 4, 582-584.

Young. D. G., Bahn, R. C., and Randall, R. V. (1965). Pituitary tumors associated with acromegaly. J. clin. Endocr., 25, 249-259.

\section{The August 1972 Issue}

\section{THE AUGUST 1972 ISSUE CONTAINS THE FOLLOWING PAPERS}

The role of fibrin deposition in diabetic glomerulosclerosis: a light, electron and immunofluorescence microscopy study A. FARQUHAR, MARY K. MacDONALD, AND J. T. IRELAND

Pulmonary fibrosis following therapy with Melphalan for multiple myeloma B. W. CODLING AND T. M. H. CHAKERA

Pathological findings after right lung transplantation in a patient with fibrosing alveolitis $\mathrm{K}$. B. SHILKIN AND LYNNE REID

The detection of fibrinogen/fibrin degradation products by means of a new antibody-coated latex particle M. BERNADETTE GARVEY AND JOAN M. BLACK

Amyloid goitre P. D. JAMES

Spontaneous infarction of superficial lymph nodes J. DOUGLAS DAVIES AND A. G. STANSFELD

Quantitative sputum culture as a means of excluding false positive reports in the routine microbiology laboratory M. J. B. WILSON AND D. E. MARTIN

A 'virus-free' cell line derived from a patient with infectious mononucleosis S. D. MARSTON, E. J. P. ALMOND, N. P. BISHUN, E. D. MAUNSELL, AND R. N. P. SUTTON

Chromosome abnormalities in chronic active hepatitis D. J. STEFANESCU, M. MOANGA, M. TEODORESCU, AND J. BRUCHER

Resistance of Staphylococcus aureus to sulphamethoxazole and trimethoprim L. S. NAKHLA
Effect of antibiotic resistance on the survival of $N$ Staphylococcus aureus R. W. LACEY

The sensitivity of diphtheria bacilli to eight antibiotics IRAJ ZAMIRI AND M. G. MCENTEGART

Serological investigations in children with colonized Spitz-Holter valves R. BAYSTON

Comparative and serial assays of folate metabolism in anticonvulsant-treated epileptics P. R. TEASDALE AND JOHN PEARCE

The measurement of serum thyroxine in childre JENNIFER RYNESS

Present day practice

An improved solubility test for haemoglobin $S$ G. A. CLARK

K.

Selective medium for the isolation of Bordetella pertussis and parapertussis ENID M. SUTCLIFFE AND J. D. ABBOTT

\section{Technical methods}

Experiences in the use of commercial antisera for the capsular typing of klebsiella species M. W. CASEWELL

Reliable routine estimation of small amounts of foetal haemoglobin by alkali denaturation M. E. PEMBREY, P. MCWADE, AND D. J. WEATHERALL

A technique for demonstrating fibrinolysis by cutaneous bacteria DOROTHY A. SOMERVILLE

Letters to the Editor

Book reviews

Copies are still available and may be obtained from the PUBLISHING MANAGER, BRITISH MEDICAL ASSOCIATION, TAVISTOCK SQUARE, LONDON, WC1H 9JR, price $£ 1.05$ 